\title{
Influence of Heat Treatment Regimes on Mechanical Properties of NSC-UHPC Composite Members
}

\section{Tadas Zingaila*, Mindaugas Augonis, Evaldas Šerelis, Šarūnas Kelpša, Deividas Martinavičius}

Kaunas University of Technology, Faculty of Civil Engineering and Architecture Studentu st. 48, LT-51367 Kaunas, Lithuania

*Corresponding author: tadas.zingaila@ktu.edu http://dx.doi.org/10.5755/j01.sace.14.1.15820
The applicability of ultra-high performance concrete which has clearly better mechanical properties than ordinary concrete is one of the most common topics in civil engineering scientific papers. Due to the high price of this type of concrete in comparison with ordinary concrete, and the absence of design codes, practical application of this type of material is still very limited, especially in less developed countries. The idea of partial usage of UHPC in some kind of structures is being developed by other scientists (Habel 2004), however it is still the lack of information about curing conditions of composite members and shear bond strength between ordinary concrete and UHPC. In order to make reliable composite structures, it is very important to ensure sufficient interface strength. In this paper experimental data is presented, which was obtained from tests carried out by authors. The aim of experiments was to establish the influence of different heat treatment regimes on mechanical properties (including shear bond strength) of normal strength concrete and ultra-high performance concrete newly cast composite members. Bi-surface shear test method was used to determine the average shear bond strength. Three different curing regimes were analysed. It was observed from preliminary tests that after heat treatment UHPC achieved its final maturity, however ordinary concrete did not gain the same strength as concrete specimens which were cured in $20{ }^{\circ} \mathrm{C}$ water for 28 days. It is a possibility that shear bond strength of heat treated composite members was significantly reduced due to the large shrinkage deformations during the short period of time. The results presented in this paper make a significant contribution to supplement the limited information about possibilities to use normal strength concrete and UHPC in new NSC-UHPC composite structures.

KEYWORDS: bi-surface shear test, shear bond strength, composite members, heat treatment, UHPC.

Ultra-high performance concrete usually is described as repair material with extraordinary mechanical properties and enhanced durability (AFGC-SETRA 2013, Harris et al. 2015, Muñoz et al. 2014). Service life of reinforced concrete structures is limited due to environment that exposes the structure, applied loads and etc., however partial use of UHPC has a potential to enhance exploitation time of reinforced concrete structures. Application of UHPC is especially important in infrastructure components. Nevertheless, understanding of material properties and structural behaviour is a major objective. The absence of UHPC structural design standards is one of the main problems in order to use this type of material in reliable manner. Despite the fact that standardised bond strength measuring method between NSC and UHPC have not been developed yet,
JSACE $1 / 14$

Influence of Heat Treatment Regimes on Mechanical Properties of NSCUHPC Composite Members

Received 2016/05/28

Accepted after revision 2016/07/05

\section{Introduction}

ktu 1922

Journal of Sustainable Architecture and Civil Engineering Vol. 1 / No. 14 / 2016 pp. 51-59 DOI 10.5755/j01.sace.14.1.15820 (c) Kaunas University of Technology 
experiments were carried out by other researches (Harris et al. 2015, Muñoz et al. 2014, Tayeh et al. 2013a, Tayeh et al. 2013b) in order to measure the bond strength between ordinary concrete and UHPC. The existing methods (slant-shear test, push-off test, and splitting tensile test) according to ASTM 882, ASTM C1583, ASTM C496 were used to measure the bond strength, respectively.

Specimens surface preparation, concrete mix composition, optimal curing conditions are another relevant topics in order to compose reliable composite members. From the tests carried out by Muñoz et al. (2014) it was determined that when the appropriate wetting conditions for substrate are achieved then the degree of surface roughness is not critical factor on the good bond strength between NSC and UHPC. However, simple surface treatment is necessary to apply in order to remove dusts and ensure excellent bond strength between composites. On purpose to determine the interfacial bond between NSC and UHPC, another experiments were carried out by Tayeh et al. (2013a) and Tayeh et al. (2013b). Under the conditions described in (Tayeh et al. 2013a, Tayeh et al. 2013b), it was determined that appropriate preparation of old surface is necessary to ensure good bond strength between NSC and UHPC composites. Mechanical bond is improved by applying surface preparation. Nagaonkar and Bhusari (2014) determined the bond strength between reactive powder concrete (RPC) and concrete (existing and fresh substrate). It was obtained higher bond strength for RPC and fresh concrete substrate. The conclusions were drawn that higher content of silica fume in RPC increases the bond strength between composites.

Despite the fact that relatively many experiments were carried out in order to determine the bond strength between old concrete substrate and new overlay of UHPC, it is still the lack of information about the shear bond strength between NSC and UHPC in new structures, taking into consideration the influence of different heat treatment regimes. It is also very important to determine the influence of heat treatment on another mechanical properties of ordinary concrete and UHPC when the objective is composite NSC-UHPC members. Experimental program on this topic was carried out and the results of experiment are presented in this paper.

\section{Methods}

\section{Bi-surface shear test}

On purpose to determine average shear bond strength between ordinary concrete and UHPC, bi-surface shear test method proposed by Momayez et al. (2002) was used in this research. Stan-

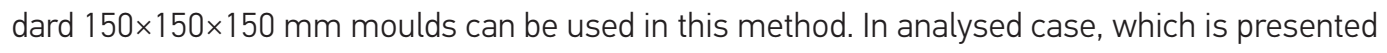
in this paper, two-thirds $(100 \mathrm{~mm})$ of the mould was filled with ordinary concrete and one-third (50 $\mathrm{mm}$ ) with UHPC. Three thick steel plates with dimensions of $150 \times 50 \times 25 \mathrm{~mm}$ were used to make direct shear between interfaces of different concrete composites (Momayez et al. 2002). Constant load of $2 \mathrm{kN} / \mathrm{s}$ (Santos et al. 2012) was applied for all bi-surface specimens.

Fig. 1

(a) scheme of bi-surface shear test, (b) example of bi-surface shear test

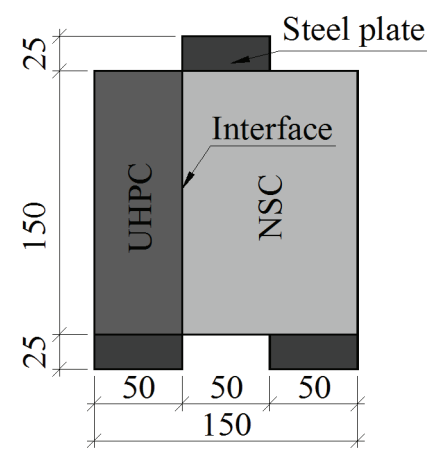

a

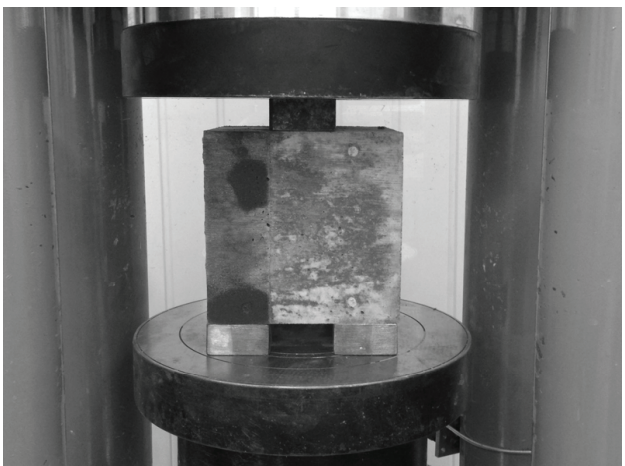

b 


\section{Heat treatment}

Atmospheric steam curing is especially important in precast concrete industry. In order to increase the amount of production, curing time takes a significant role. After steam curing concrete gains higher strength in early age and the moulds can be soon used for other products (Tikalsky and Jonassen 2016). It is general recommendation do not exceed about $65^{\circ} \mathrm{C}$ temperature when heat curing is applied for concrete in early age. High temperature accelerates concrete strength in early age, however influences on lower strength after 28 days or on ultimate strength (Shetty 2013).

As it is described in AFGC-SETRA (2013), heat treatment applied to UHPFRC improves its mechanical properties. There are distinguished two different heat treatment regimes which can be applied to UHPFRC independently of one another. The first type of heat treatment can be called as heat curing and is applied during the first few hours after casting of concrete. The temperature of heat treatment has to be less than $65^{\circ} \mathrm{C}$ on purpose to avoid delayed ettringite formation. The second type of heat treatment is applied when the concrete is hardened and the applied temperature has to be about $90^{\circ} \mathrm{C}$.

From the point of view of composite structures, it is necessary that the temperature of heat treatment would be optimal for both composites - concrete and UHPC. In order to make comparisons, some of advantages and disadvantages of heat treated UHPC and not heat treated concrete are presented in Table 1. It should be noted that the data presented in Table 1 is general and actual properties can be different depending on specified case.

\begin{tabular}{|c|c|c|c|}
\hline \multicolumn{4}{|c|}{ Normal strength concrete - ultra high performance concrete composite members } \\
\hline \multicolumn{2}{|c|}{ UHPC with heat treatment } & \multicolumn{2}{|c|}{ NSC without heat treatment } \\
\hline Advantages & Disadvantages & Advantages & Disadvantages \\
\hline 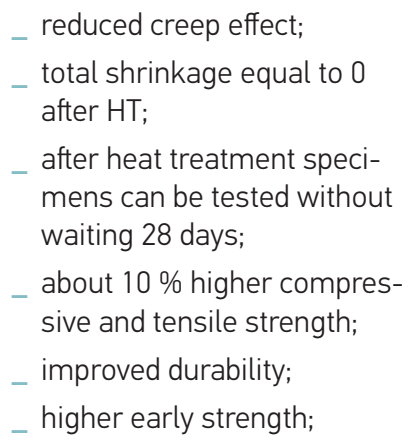 & $\begin{array}{l}\text { _ higher energy } \\
\text { costs; } \\
\text { _ difficult to carry } \\
\text { out and control } \\
\text { the process; } \\
\text { _ requires good } \\
\text { knowledge; }\end{array}$ & $\begin{array}{l}\text { _ higher final strength } \\
\text { of normal strength } \\
\text { concrete when it is } \\
\text { compared to steam } \\
\text { cured concrete; } \\
\text { _ avoids delayed } \\
\text { ettringite formation; } \\
\text { _ avoid internal crack- } \\
\text { ing; } \\
\text { _- lower energy costs; }\end{array}$ & 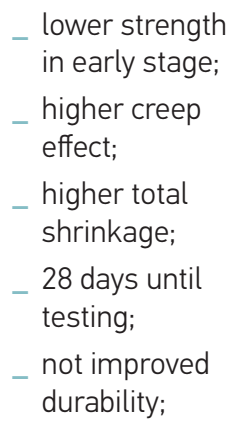 \\
\hline
\end{tabular}

The main mechanical properties of ordinary concrete are given in design standard EN 1992-11:2004 (Eurocode 2). Ultra-high performance concrete is more recent material and there are no design standards, where would be possibility to find UHPC classification according to compressive strength and other mechanical properties. There are only interim recommendations for UHPFRC (AFGC-SETRA, 2013).

When it is necessary to obtain optimal mechanical properties of NSC-UHPC composite members, situation becomes even more complicated. In order to find the influence of heat treatment on mechanical properties of composite members and try to find optimal case, three different cases were analysed in this paper. Concrete and UHPC mix compositions used in experiment are given in Table 2 and Table 3.

\section{Table 1}

Advantages and disadvantages of heat treatment on concrete and UHPC (AFGC-SETRA 2013; Tikalsky and Jonassen 2016, Shetty 2013, Skripkiūnas 2007)

\section{Experiment}




\section{Table 2}

UHPC mix composition $(\mathrm{W} / \mathrm{C}$ ratio 0.21$)$

Table 3

Concrete mix composition (W/C ratio 0.47 )

\section{Fig. 2}

Scheme of experimental program

\begin{tabular}{l|c}
\multicolumn{1}{c|}{ Material } & Quantity, $\mathrm{kg} / \mathrm{m}^{3}$ \\
\hline Cement CEM I 52.5 R & 735 \\
\hline Water & 152 \\
\hline Silica fume & 99 \\
\hline Glass powder & 412 \\
\hline Quartz sand (0/2 fr.) & 962 \\
\hline Superplasticizer & 36.76
\end{tabular}

\begin{tabular}{l|c}
\multicolumn{1}{c|}{ Material } & Quantity, $\mathrm{kg} / \mathrm{m}^{3}$ \\
\hline Cement CEM I 42.5 R & 318 \\
\hline Water & 150 \\
\hline Coarse aggregate (gravel 4/16 fr.) & 960 \\
\hline Fine aggregate (sand 0/4 fr.) & 945 \\
\hline Superplasticizer & 1.91 \\
\hline
\end{tabular}

All specimens were cast and tested according to available standards. Geometry of the specimens to determine different mechanical properties were used as follows: compressive strength - cubes $100 \times 100 \times 100 \mathrm{~mm}$, flexural tensile strength - prisms $100 \times 100 \times 400 \mathrm{~mm}$, secant modulus of elasticity - prisms $100 \times 100 \times 300 \mathrm{~mm}$, shear bond strength cubes $150 \times 150 \times 150 \mathrm{~mm}$.

Considering to the fact that the experiment was carried out in order to find the way how to produce new flexural composite members, it was chosen to cast both composites while they are in fresh condition (the second layer was cast during the first hour after the first layer was prepared). The surface between composites was left natural as it formed after vibration. The specimens were removed from moulds when passed $24 \mathrm{~h}$ hours after casting.

On purpose to save costs the specimens were heat treated in $65{ }^{\circ} \mathrm{C}$ and $90^{\circ} \mathrm{C}$ temperature water for 24 hours instead of 48 hours, then the device was turned off and the same time the specimens were left in hot water, while the temperature of water dropped down naturally. Heat treated specimens were tested after 3 days from casting.

Scheme of experimental program is presented in Fig. 2.

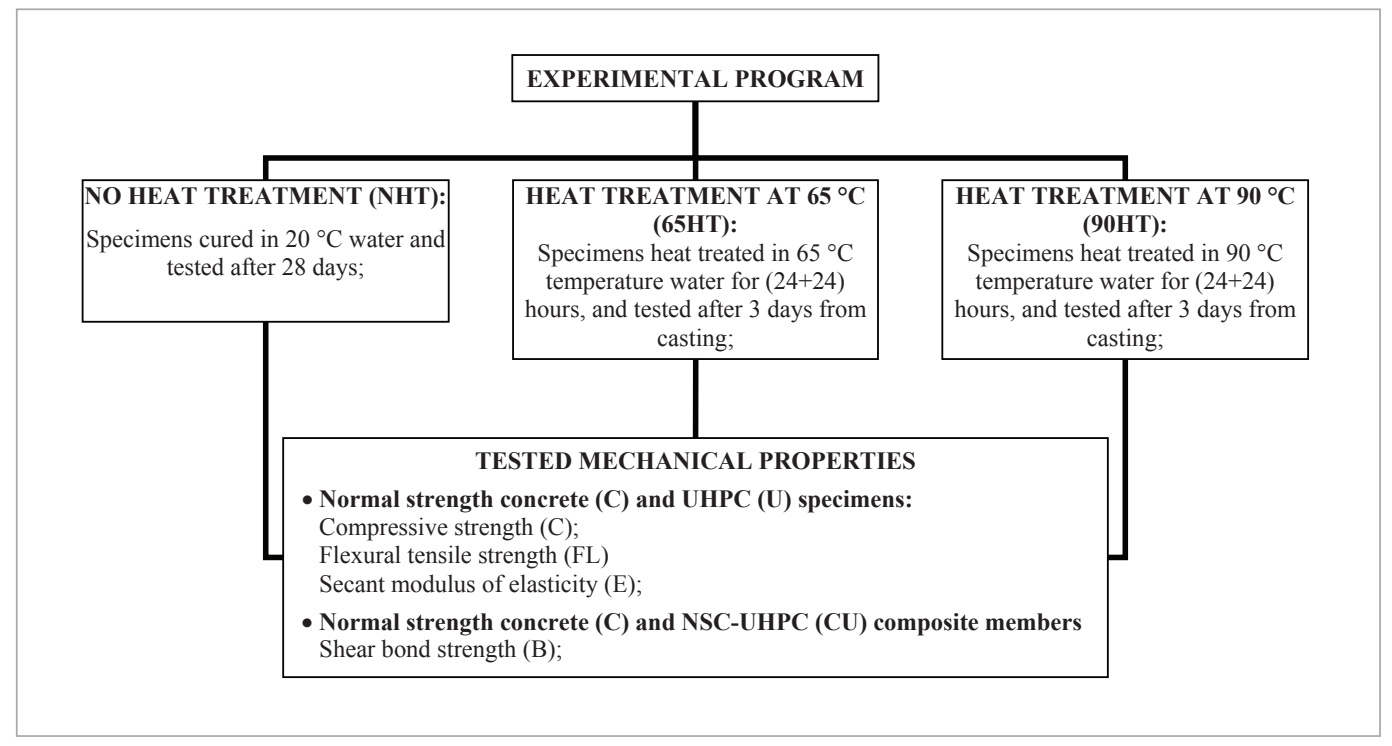

Results of concrete and UHPC average compressive strength are presented in Table 4. It can be seen that the best compressive strength of concrete cubes was obtained when the specimens were cured in $20^{\circ} \mathrm{C}$ water for 28 days period. The concrete specimens which were heat treated in $65{ }^{\circ} \mathrm{C}$ and $90{ }^{\circ} \mathrm{C}$ temperature water showed lower values of compressive strength $25.92 \%$ and $33.14 \%$, respectively. It should be noted that both $\mathbf{C}-\mathbf{C}-\mathbf{6 5 H T}$ and $\mathbf{C}-\mathbf{C}-\mathbf{9 0 H T}$ series of specimens 
with the same mix composition were tested after 3 days from casting. Therefore, $7.22 \%$ difference between results shows that the temperature of heat treatment has some influence on the values of mechanical properties. However, two interpretations of results can be distinguished when it is compared to reference specimens. The first interpretation can be defined that the loss of strength was due to high temperature, and microstructure of concrete was damaged. In the second case it can be stated that heat treated specimens were tested after 3 days from casting and the strength of cubes after heat treatment was only about $60-75 \%$ of cubes which were tested after 28 days, and later the strength will increase. However, it can be found in literature (Tikalsky and Jonassen 2016, Shetty 2013, Skripkiūnas 2007) that concrete specimens heat treated at high temperature have higher early strength of concrete, but the final strength is lower than for the specimens which where cured 28 days in normal conditions. In any case the strength of concrete in early period of composite NSC-UHPC structural member would be lower than reference specimen $\boldsymbol{C}$ - $\boldsymbol{C}$-NHT. This is some disadvantage, because UHPC after heat treatment reach its final maturity without waiting 28 days (AFGC-SETRA, 2013).

Under the conditions of analysed case, the influence of heat treatment temperature on average compressive strength of UHPC cubes was especially insignificant. When compare to reference cubes $\mathbf{C}-\boldsymbol{U}-\mathbf{N H T}$, the strength of $\boldsymbol{C}-\boldsymbol{U}-\mathbf{6 5 H T}$ and $\boldsymbol{C}-\boldsymbol{U}-\mathbf{6 5 H T}$ cubes were $1.14 \%$ and $0.96 \%$ higher, respectively. However, it should be noted that another mechanical properties of concrete would be better after heat treatment at high temperature (zero total shrinkage, reduced creep, increased durability (AFGC-SETRA, 2013)).

\begin{tabular}{|c|c|c|c|c|c|c|c|}
\hline $\begin{array}{l}\text { Specimen } \\
\text { type }\end{array}$ & $\begin{array}{l}\text { Average } \\
\mathrm{f}_{\mathrm{cm}}, \mathrm{MPa}\end{array}$ & $\begin{array}{c}\text { Standard } \\
\text { deviation, } \\
\mathrm{MPa}\end{array}$ & COV, \% & $\begin{array}{l}\text { Specimen } \\
\text { type }\end{array}$ & $\begin{array}{l}\text { Average } \\
\mathrm{f}_{\mathrm{cm}}, \mathrm{MPa}\end{array}$ & $\begin{array}{c}\text { Standard } \\
\text { deviation, } \\
\text { MPa }\end{array}$ & COV, \% \\
\hline C-C-NHT & $\begin{array}{l}52.27 \\
(100)\end{array}$ & 3.143 & 6.014 & $C-U-N H T$ & $\begin{array}{l}145.33 \\
(100)\end{array}$ & 3.71 & 2.55 \\
\hline C-C-65HT & $\begin{array}{c}38.72 \\
\mathbf{( 7 4 . 0 8 )}\end{array}$ & 0.79 & 2.03 & $C-U-65 H T$ & $\begin{array}{c}146.97 \\
(101.14)\end{array}$ & 10.21 & 6.95 \\
\hline C-C-9OHT & $\begin{array}{c}34.95 \\
(66.86)\end{array}$ & 0.43 & 1.24 & C-U-90HT & $\begin{array}{c}146.73 \\
(100.96)\end{array}$ & 7.97 & 5.43 \\
\hline
\end{tabular}

*explanations of abbreviations are given in Fig. 2 .

The results of average flexural tensile strength are presented in Table 5. Flexural tensile strength of ordinary concrete prisms was lower when heat treatment was applied. In comparison with reference specimen without heat treatment the strength of $F L-C-65 H T$ and $F L-C-90 H T$ was lower $19.47 \%$ and $28.6 \%$, respectively. The difference between heat treated specimens was $9.13 \%$ when compare to reference specimens. Under this experiment conditions flexural tensile strength of UHPC prisms, that where heat treated in $65^{\circ} \mathrm{C}$ temperature water showed the lowest values when compare to $F L-U-N H T$ and $F L-U-90 H T$ specimens. Due to a reason to find optimal curing conditions for both type of composites (concrete and UHPC), this type of heat treatment was applied after the concrete has set. According to AFGC-SETRA (2013), heat treatment at $65^{\circ} \mathrm{C}$ is applied at the moment when UHPC starts to set and its aim is to accelerate initial hardening. It is a possibility that the applied temperature was enough to reach compressive strength of UHPC similar to another two cases $(\boldsymbol{C}-\boldsymbol{U}-\mathbf{N H T}$ and $\mathbf{C}-\boldsymbol{U}-\mathbf{9 0 H T})$, however the final maturity in tension was not reached at this temperature. The difference of flexural tensile strength between the specimens which were heat treated in $90{ }^{\circ} \mathrm{C}$ temperature water and cured 28 days in water was insignificant $-0.3 \%$.

\section{Table 4}

Compressive strength of concrete and UHPC at different heat treatment regimes 
Table 5

Flexural tensile strength of concrete and UHPC at different heat treatment regimes

\section{Table 6}

Secant modulus of elasticity of concrete and UHPC at different heat treatment regimes

\begin{tabular}{c|c|c|c|c|c|c|c}
\hline $\begin{array}{c}\text { Specimen } \\
\text { type }\end{array}$ & $\begin{array}{c}\text { Average } \\
\mathrm{f}_{\mathrm{ctm}, \mathrm{fl}}, \mathrm{MPa}\end{array}$ & $\begin{array}{c}\text { Standard } \\
\text { deviation, MPa }\end{array}$ & COV, \% & $\begin{array}{c}\text { Specimen } \\
\text { type }\end{array}$ & $\begin{array}{c}\text { Average } \\
\mathrm{f}_{\mathrm{ctm}, \mathrm{fl}}, \mathrm{MPa}\end{array}$ & $\begin{array}{c}\text { Standard } \\
\text { deviation, MPa }\end{array}$ & COV, \% \\
\hline FL-C-NHT & $\begin{array}{c}5.70 \\
(\mathbf{1 0 0 )}\end{array}$ & 0.38 & 6.62 & FL-U-NHT & $\begin{array}{c}16.71 \\
\mathbf{( 1 0 0 )}\end{array}$ & 1.40 & 8.35 \\
\hline FL-C-65HT & $\begin{array}{c}4.59 \\
(\mathbf{8 0 . 5 3 )}\end{array}$ & 0.17 & 3.70 & FL-U-65HT & $\begin{array}{c}14.46 \\
\mathbf{( 8 6 . 5 4 )}\end{array}$ & 0.33 & 2.25 \\
\hline FL-C-90HT & $\begin{array}{c}4.07 \\
(\mathbf{7 1 . 4 0 )}\end{array}$ & 0.16 & 4.05 & FL-U-90HT & $\begin{array}{c}16.66 \\
\mathbf{( 9 9 . 7 0 )}\end{array}$ & 0.90 & 5.43 \\
\hline
\end{tabular}

*explanations of abbreviations are given in Fig. 2.

Similar to compressive strength tendencies were observed with secant modulus of elasticity. For ordinary concrete the higher the temperature was applied the lower secant modulus of elasticity was obtained. However, different interpretations of results can be stated as discussed above about the compressive strength of concrete. The differences between secant modulus of elasticity of UHPC in all three analysed cases were insignificant. Comparison of results is given in Table 6.

\begin{tabular}{c|c|c|c|c|c|c|c}
\hline $\begin{array}{c}\text { Specimen } \\
\text { type }\end{array}$ & $\begin{array}{c}\text { Average } \\
\mathrm{E}_{\mathrm{cm}}, \mathrm{GPa}\end{array}$ & $\begin{array}{c}\text { Standard } \\
\text { deviation, GPa }\end{array}$ & COV, \% & $\begin{array}{c}\text { Specimen } \\
\text { type }\end{array}$ & $\begin{array}{c}\text { Average } \mathrm{E}_{\mathrm{cm}} \\
\mathrm{GPa}\end{array}$ & $\begin{array}{c}\text { Standard } \\
\text { deviation, GPa }\end{array}$ & CoV, \% \\
\hline E-C-NHT & $\begin{array}{c}29.85 \\
(\mathbf{1 0 0}\end{array}$ & 0.79 & 2.65 & E-U-NHT & $\begin{array}{c}41.31 \\
\mathbf{( 1 0 0 )}\end{array}$ & 0.82 & 1.97 \\
\hline E-C-65HT & $\begin{array}{c}29.28 \\
(\mathbf{9 8 . 0 9 )}\end{array}$ & 0.63 & 2.14 & E-U-65HT & $\begin{array}{c}42.52 \\
\mathbf{( 1 0 2 . 9 3 )}\end{array}$ & 0.08 & 0.18 \\
\hline E-C-90HT & $\begin{array}{c}26.07 \\
(\mathbf{8 7 . 3 3 )}\end{array}$ & 0.23 & 0.87 & E-U-90HT & $\begin{array}{c}41.26 \\
\mathbf{( 9 9 . 8 8 )}\end{array}$ & 0.02 & 0.05 \\
\hline
\end{tabular}

*explanations of abbreviations are given in Fig. 2.

The most important aim and practical application of experiment were to ensure the sufficient shear bond strength in the plane between concrete and UHPC in newly cast flexural composite NSC-UHPC members, and achieve optimal concrete and UHPC mechanical properties. There are a lot of different factors, which have influence on shear bond strength between different composites, therefore, due to this reason it is difficult to distinguish what is the influence of heat treatment and how many influence have another factors. The example of flexural composite NSC-UHPC member is presented in Fig. 3. It should be noted that the position of layers in the cross-section could be different (UHPC in compression zone, in both zones, etc.).

Fig. 3

Flexural composite NSCUHPC member

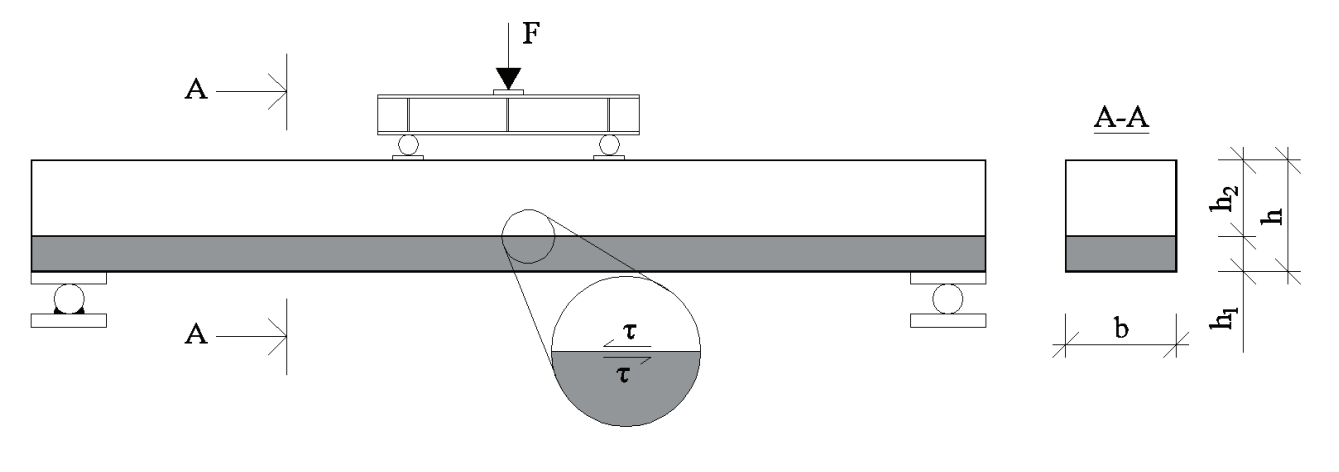


Composite NSC-UHPC specimens which were used in experiment are presented in Fig. 4., before testing (a) and after testing (b) and (c). In comparison to composite cubes, continuous specimens made from ordinary concrete also were cast and specimen after failure is presented in Fig. 4 (d).

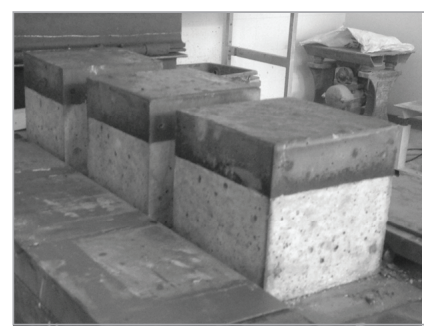

a

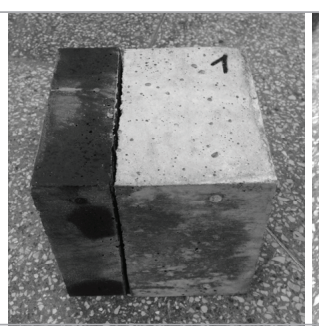

b

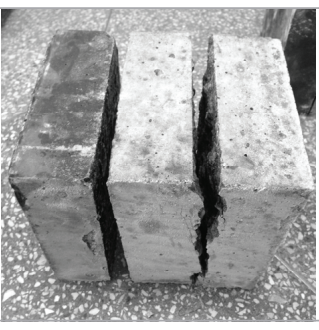

C

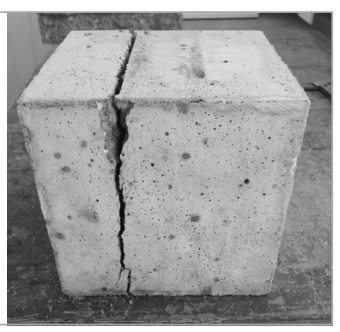

d
Fig. 4

(a) composite specimens, (b) and (c) composite specimens after failure, (d) continuous concrete cube after failure

As it was preliminary supposed, the average shear bond strength of continuous concrete specimens in all cases was higher than the bond strength in shear of composite members. The results of shear bond strength are presented in Table 7. For continuous concrete specimens almost the same influence of different heat treatment regimes as for compressive concrete specimens can be observed. Heat treated specimens had lower strength, but the lowest one in this case was not achieved at the highest temperature. However, this could be explained due to the relatively large scatter of results in bond shear strength, coefficient of variation is up to $18.06 \%$.

It is more difficult to analyse the results of composite NSC-UHPC specimens, because there are many factors which can do influence on strength in shear plane between composites. Surface roughness, different curing conditions, different shrinkage deformations and difference between secant modulus of elasticity play significant role on shear bond strength of composite members (Santos and Júlio 2010). Under this experiment conditions, the best results were obtained for composite specimens without heat treatment and the average shear bond strength was equal to $5.01 \mathrm{MPa}$. It was taken as reference specimen. The specimens which were heat treated in $65^{\circ} \mathrm{C}$ and $90{ }^{\circ} \mathrm{C}$ temperature had lower strength than reference specimen $62.87 \%$ and $60.48 \%$, respectively. It should be noted that in all three cases the scatter of results was large. Coefficient of variation was $38.30 \%, 43.40 \%$ and $27.62 \%$, respectively. This could be explained that the influence of heat treatment on shear bond strength in early period of composite NSC-UHPC is a partial.

\begin{tabular}{|c|c|c|c|c|c|c|c|c|c|}
\hline $\begin{array}{l}\text { Specimen } \\
\text { type }\end{array}$ & $\begin{array}{l}\text { Average } \\
\tau, \mathrm{MPa}\end{array}$ & $\begin{array}{c}\text { Standard } \\
\text { deviation, } \\
\mathrm{MPa}\end{array}$ & cov, $\%$ & $\begin{array}{l}\text { Failure } \\
\text { mode }\end{array}$ & $\begin{array}{l}\text { Specimen } \\
\text { type }\end{array}$ & $\begin{array}{c}\text { Average } \\
\tau, \mathrm{MPa}\end{array}$ & $\begin{array}{c}\text { Standard } \\
\text { deviation, } \\
\mathrm{MPa}\end{array}$ & cov, \% & $\begin{array}{l}\text { Failure } \\
\text { mode }\end{array}$ \\
\hline$B-C-N H T$ & $\begin{array}{l}10.30 \\
(100)\end{array}$ & 0.83 & 8.05 & $\begin{array}{l}2 \text { planes } \\
1 \text { plane } \\
1 \text { plane }\end{array}$ & $B-C U-N H T$ & $\begin{array}{l}5.01 \\
(100)\end{array}$ & 1.92 & 38.30 & $\begin{array}{l}\text { Interface } \\
2 \text { planes } \\
\text { Interface }\end{array}$ \\
\hline$B-C-65 H T$ & $\begin{array}{c}7.91 \\
(76.80)\end{array}$ & 1.43 & 18.06 & $\begin{array}{l}2 \text { planes } \\
1 \text { plane } \\
2 \text { planes }\end{array}$ & $B-C U-65 H T$ & $\begin{array}{c}1.86 \\
(37.13)\end{array}$ & 0.81 & 43.40 & $\begin{array}{l}\text { Interface } \\
\text { Interface } \\
\text { Interface }\end{array}$ \\
\hline B-C-90HT & $\begin{array}{c}8.52 \\
(82.72)\end{array}$ & 0.51 & 6.00 & $\begin{array}{l}1 \text { plane } \\
1 \text { plane } \\
1 \text { plane }\end{array}$ & $B-C U-90 H T$ & $\begin{array}{c}1.98 \\
(39.52)\end{array}$ & 0.55 & 27.62 & $\begin{array}{l}\text { Interface } \\
\text { Interface } \\
\text { Interface }\end{array}$ \\
\hline
\end{tabular}

Table 7

Shear bond strength of concrete and concreteUHPC composite members at different heat treatment regimes

\footnotetext{
*explanations of abbreviations are given in Fig. 2.
} 
1 The results of carried out experiments can be described in two different interpretations. In the first case, it could be stated that after heat treatment in $65^{\circ} \mathrm{C}$ and $90^{\circ} \mathrm{C}$ temperature water, the mechanical properties of ordinary concrete specimens were negatively affected in comparison to specimens cured in $20^{\circ} \mathrm{C}$ water for 28 days. In the second case, it could be stated that after heat treatment ordinary concrete specimens were tested after 3 days from casting, therefore the concrete did not reach its final maturity and the strength after 28 days will be similar as for non-heat treated specimens. However, it can be seen some differences in strength at different temperatures $\left(65^{\circ} \mathrm{C}\right.$ and $\left.90^{\circ} \mathrm{C}\right)$. The lower strength at higher temperature. Testing after 3 days were chosen in order to check a possibility to use concrete-UHPC composite members without waiting for 28 days. As it is described in AFGC-SETRA (2013) recommendations, UHPC reaches its final maturity after heat treatment in $90^{\circ} \mathrm{C}$. On purpose to draw more clear conclusions, it is necessary to cast additional concrete specimens, then after heat treatment in $65^{\circ} \mathrm{C}$ and $90^{\circ} \mathrm{C}$ temperature wait up to 28 days until testing and make the comparisons.

From the point of view of composite NSC-UHPC members it is difficult to define optimal $\angle$ curing conditions, however without heat treatment UHPC lose some advantages. Also it is a possibility that flexural composite concrete-UHPC members without heat treatment would have larger long-term deformations in comparison to heat treated members.

3 Negative influence of heat treatment on shear bond strength between concrete and UHPC could be partly explained due to the large shrinkage deformations during the short period of time. However, the scatter of results was significantly large, therefore it means that the influence of heat treatment is only a partial and it is difficult to distinguish it from other factors contribution.

\section{References}

AFGC-SETRA. Ultra-high performance fibre-reinforced concretes - Interim recommendations, France, 2013.

EN 1992-1-1:2004. Eurocode 2: Design of concrete structures - Part 1-1: General rules and rules for buildings.

Habel, K. Structural behaviour of elements combining ultra-high performance fibre reinforced concretes (UHPFRC) and reinforced concrete. Doctoral thesis No. 3036, Ecole Polytechnique Fédérale de Lausanne (EPFL), 2004.

Harris D.K., Muñoz M.A.C., Gheitasi A., Ahlborn T.M., Rush S.V. The challenges related to interface bond characterization of ultra-high-performance concrete with implications for bridge rehabilitation practices. Advances in Civil Engineering Materials, 2015; 4(2): 1-27. http://dx.doi:10.1520/ACEM20140034

Momayez A., Ramezanianpour A., Rajaie H., Ehsani M.R. Experimental investigation of the methods of evaluating the bond strength between concrete substrate and repair materials. International Journal of Engineering, Transactions B: Applications, 2002; 15(4): 319-332.

Momayez A., Ramezanianpour A.A., Rajaie H., Ehsani M.R. Bi-surface shear test for evaluating bond between existing and new concrete. ACl Materials Journal, 2004; 101(2): 99-106.

Momayez A., Ehsani M.R., Ramezanianpour A.A., Rajaie $\mathrm{H}$. Comparison of methods for evaluating bond strength between concrete substrate and repair materials. Cement and Concrete Research, 2005; 35(4): 748-757.

Muñoz C.M., Harris, D., Ahlborn T., Froster D. Bond performance between ultrahigh-performance concrete and normal-strength concrete. Journal of Materials in Civil Engineering, 2014; 26(8). http:// dx.doi.org/10.1061/(ASCE)MT.1943-5533.0000890

Nagaonkar D.S., and. Bhusari J.P. Characterization of reactive powder concrete with respect to its bond strength. International Journal of Scientific \& Engineering Research, 2014; 5(5): 279-282.

Santos D.S., Santos P.M.D., Dias-da-Costa D. Effect of surface preparation and bonding agent on the concrete-to-concrete interface strength. Construction and Building Materials, 2012; 37: 102-110. http://dx.doi.org/10.1016/j.conbuildmat.2012.07.028

Santos P.M.D., Júlio, E.N.B.S. Recommended improvements to current shear-friction provisions of Model Code. In: 3rd fib international congress, Washington, DC, May 29-June 02, 2010. 
Shetty M.S. Concrete technology: theory and practice (7 ed.). India: S. Chand \& Company Pvt. Ltd.; 2013.

Skripkiūnas G. Statybinių konglomeratų struktūra ir savybès. Kaunas: Vitae Litera; 2007.

Tayeh B.A., Bakar B.H.A., Johari M.A.M. Characterization of the interfacial bond between old concrete substrate and ultra high performance fiber concrete repair composite. Materials and Structures, 2013a; 46(5), 743-753. DOI: 10.1617/s11527-012-9931-1
Tayeh B.A., Bakar B.H.A., Johari M.A.M., Voo Y.L. Evaluation of bond strength between normal concrete substrate and ultra high performance fiber concrete as a repair material. Procedia Engineering, 2013b; 54: 554-563. http://dx.doi.org/10.1016/j.proeng.2013.03.050

Tikalsky P.J., Jonassen D. Available on internet [2016-05-16]:

http://www.engr.psu.edu/ce/courses/ce584/concrete/library/construction/curing/Accelerating $\% 20$ strength\%20gain.htm

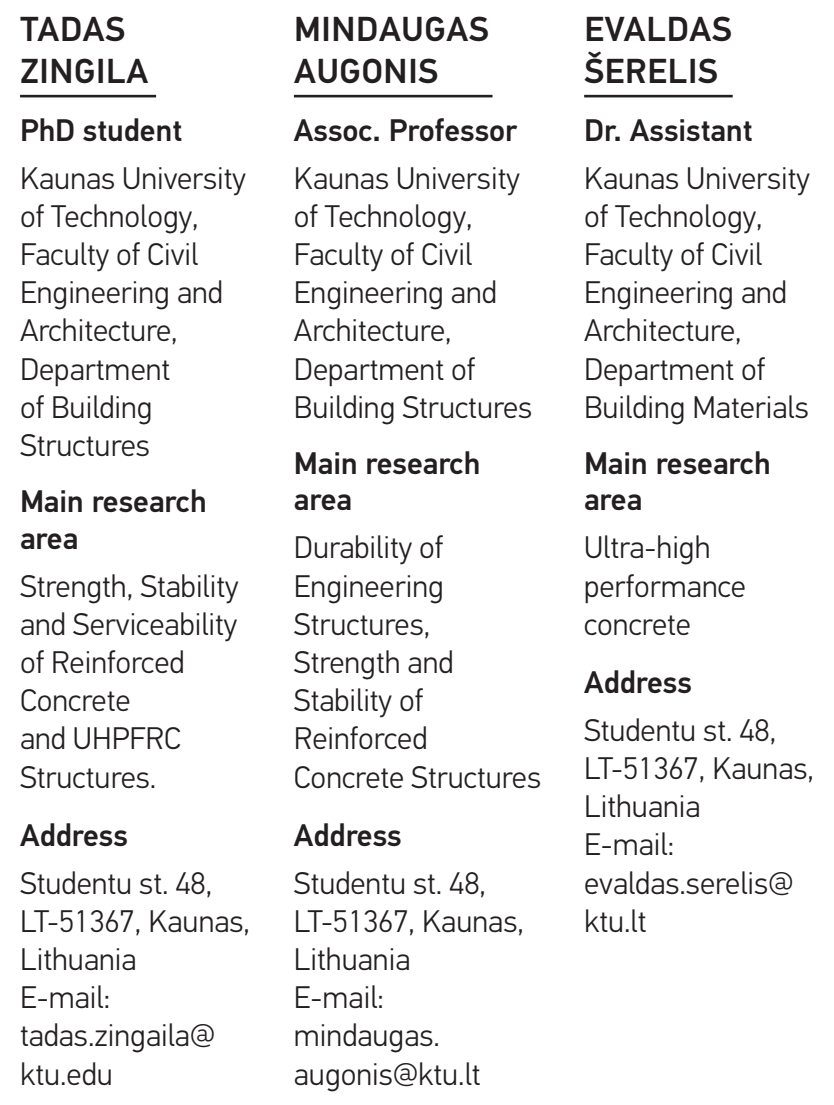

\begin{tabular}{|c|c|}
\hline $\begin{array}{l}\text { ŠARŪNAS } \\
\text { KELPŠA }\end{array}$ & $\begin{array}{l}\text { DEIVIDAS } \\
\text { MARTINAVIČIUS }\end{array}$ \\
\hline $\begin{array}{l}\text { Assistant } \\
\text { Kaunas University }\end{array}$ & $\begin{array}{l}\text { Master's degree } \\
\text { student }\end{array}$ \\
\hline $\begin{array}{l}\text { of Technology, } \\
\text { Faculty of Civil } \\
\text { Engineering and } \\
\text { Architecture, } \\
\text { Department of } \\
\text { Building Structures }\end{array}$ & $\begin{array}{l}\text { Kaunas University } \\
\text { of Technology, } \\
\text { Faculty of Civil } \\
\text { Engineering and } \\
\text { Architecture, } \\
\text { Department of }\end{array}$ \\
\hline $\begin{array}{l}\text { Main research } \\
\text { area } \\
\text { Strength, Stability }\end{array}$ & $\begin{array}{l}\text { Main research } \\
\text { area }\end{array}$ \\
\hline $\begin{array}{l}\text { and Serviceability } \\
\text { of Reinforced } \\
\text { Concrete } \\
\text { Structures. }\end{array}$ & $\begin{array}{l}\text { Calculation and } \\
\text { analysis of building } \\
\text { structures. }\end{array}$ \\
\hline Address & Studentu st. 48, \\
\hline $\begin{array}{l}\text { Studentu st. 48, } \\
\text { LT-51367, Kaunas, } \\
\text { Lithuania } \\
\text { E-mail: } \\
\text { sarunas.kelpsa@ } \\
\text { ktu.lt }\end{array}$ & $\begin{array}{l}\text { LT-51367, Kaunas, } \\
\text { Lithuania } \\
\text { E-mail: } \\
\text { deividas. } \\
\text { martinavicius@ } \\
\text { ktu.edu }\end{array}$ \\
\hline
\end{tabular}

